\title{
The cost of individual health care in Serbia according to the international classification of diseases in the period 2010-2015
}

\author{
Milena Gajić-Stevanović ${ }^{1}$, Periša Simonović ${ }^{1}$, Dušica Banković-Lazarević ${ }^{1}$ Ivan Stevanović ${ }^{2}$, \\ Lidija Stanković \\ "Institute of Public Health of Serbia "Milan Jovanovic-Batut", Belgrade, Serbia; \\ ${ }^{2} \mathrm{ABC}$ Tutor
}

\begin{abstract}
SUMMARY
Introduction There is growing interest in the world for estimating the cost for the treatment of a disease. This value can be used to determine to which extent a particular disease or group of diseases burden society in terms of the global crisis (Segel 2006). In 2000, Organization for Economic Countries Development (OECD) established a System of Health Accounts (SHA), and provided methodological guide for calculating the cost of treating the disease.

The aim of this study was to determine the cost of individual health care in the Republic of Serbia according to the major International Classification of Diseases (ICD) for the period 2010-2015.

Material and Methods A retrospective and comparative analysis of health statistics from the database of the Institute of Public Health of Serbia (IPHS) and financial information provided by the National Health Insurance Fund (NHIF) in the period 2010-2015 was performed. Financial information and data on hospital services, outpatient, home health care, auxiliary health care services, drug consumption and consumer goods in healthcare were analyzed using SHA methodology.

Results showed that during observation period the maximum cost of individual health care in Serbia by main classification ICD was achieved in 2015 and it was 194,128,864,011 RSD $(€ 1,580,853,941 ; \$ 1,764,807,854)$ and the minimal cost was achieved in $2010,151,333,139,835$ RSD ( $€ 1,434,464,541 ; \$ 1,908,843,843)$.

Conclusion The cost of individual health care in the Republic of Serbia in the period 2010-2015 increased by thirty percent. The highest amount was allocated to treat people with diseases of the circulatory system.

Keywords: cost of the disease; health spending; health accounts; cardiovascular diseases
\end{abstract}

\section{INTRODUCTION}

Health care is one of the most important human activities and one of the most dynamic in terms of growth in expenses for its delivery. Numerous achievements in medicine, pharmaceuticals and medical technologies improve health status of people in most countries, but they also increase the cost. Therefore, the focus of health policy is to establish efficacy but also the effectiveness of health care. Health care costs are a burden that particular disease or group of diseases put on society [1].

Realistic presentation of financial data in health care, in particular those relating to the monitoring costs for the treatment of patients with certain diseases are absolutely necessary. In the recent years, there was growing interest for calculating the costs of treating patients $[2,3,4]$, that have certain diseases [5-16], injuries [17] disorders [18] and conditions [19-24].

In 2000, Organization for Economic Development of countries (OECD) established the System of Health Accounts (SHA) that formulated indicative methodological guidance for calculating the cost of treating patients through the Table 6. Until the initiation of new Method- ological guidelines SHA 2011, the Table 6 in SHA was used [25], as part of the National Health Accounts (NHA). That Table provides the current cost of health care according to the main groups of disorders by the International Classification of Diseases (ICD).

In the system of health accounts an individual health care costs are defined as those costs in the health system that do not involve shared health care like public health services, collective prevention, health insurance, health administration and costs for performing functions related to the health care.

The aim of this study was to perform a comparative analysis of the costs of individual health care in the Republic of Serbia by main groups of diseases (ICD) for the period 2010-2015.

\section{MATERIALS AND METHODS}

A comparative retrospective analysis of statistical data from the database of the Institute of Public Health of Serbia (IPHS) and financial data of the National Health Insurance Fund (NHIF) for the period 2010-2015 was performed. 
Table 1. Groups of diseases according to the International Classification of Diseases (ICD), and methodology for the preparation of the table 6 NHA based on the SHA (version 1)

Tabela 1. Grupa oboljenja prema Međunarodnoj klasifikaciji bolesti (MKB) i metodologija za izradu tabele 6 NZR na osnovu SZR (verzija 1)

\begin{tabular}{|c|c|}
\hline $\begin{array}{l}\text { Code } \\
\text { Šifra }\end{array}$ & $\begin{array}{l}\text { Groups of diseases } \\
\text { Grupe oboljenja }\end{array}$ \\
\hline A A00-B99 & $\begin{array}{l}\text { Infectious and parasitic diseases } \\
\text { Infektivne i parazitske bolesti }\end{array}$ \\
\hline C C $00-D 48$ & $\begin{array}{l}\text { Neoplasms } \\
\text { Tumori }\end{array}$ \\
\hline D D50-D89 & $\begin{array}{c}\text { Diseases of the blood and blood-forming organs } \\
\text { Bolesti krvi i krvotvornih organa }\end{array}$ \\
\hline E E00-E90 & $\begin{array}{l}\text { Endocrine and metabolic diseases } \\
\text { Endokrine bolesti i bolesti metabolizma }\end{array}$ \\
\hline F F00-F99 & $\begin{array}{c}\text { Mental disorders } \\
\text { Mentalni poremećaji }\end{array}$ \\
\hline G G00-G99 & $\begin{array}{c}\text { Diseases of the nervous system } \\
\text { Bolesti nervnog sistema }\end{array}$ \\
\hline $1100-199$ & $\begin{array}{l}\text { Diseases of the circulatory system } \\
\text { Bolesti cirkulatornog sistema }\end{array}$ \\
\hline נر J J00-J99 & $\begin{array}{c}\text { Diseases of the respiratory system } \\
\text { Bolesti disajnog sistema }\end{array}$ \\
\hline К К00-К93 & $\begin{array}{l}\text { Diseases of the digestive system } \\
\text { Bolesti digestivnog sistema }\end{array}$ \\
\hline L L00-L99 & $\begin{array}{l}\text { Skin and subcutaneous tissue disorders } \\
\text { Bolesti kože i potkožnog tkiva }\end{array}$ \\
\hline M M00-M99 & $\begin{array}{l}\text { Diseases of the musculoskeletal system } \\
\text { Bolesti mišićno-koštanog sistema }\end{array}$ \\
\hline N N00-N99 & $\begin{array}{c}\text { Diseases of the genitourinary system } \\
\text { Bolesti urogenitalnog sistema }\end{array}$ \\
\hline $0000-099$ & $\begin{array}{l}\text { Complications of pregnancy and childbirth } \\
\text { Komplikacije trudnoće i porođaja }\end{array}$ \\
\hline P P00-P96 & $\begin{array}{l}\text { Perinatal conditions } \\
\text { Perinatalna stanja }\end{array}$ \\
\hline Q Q00-Q99 & $\begin{array}{l}\text { Congenital malformations } \\
\text { Urođene anomalije }\end{array}$ \\
\hline R R00-R99 & $\begin{array}{l}\text { Symptoms and pathologies } \\
\text { Simptomi i patološka stanja }\end{array}$ \\
\hline S S00-T98 & $\begin{array}{l}\text { Injuries, poisoning and consequences } \\
\text { Povrede, trovanja i posledice }\end{array}$ \\
\hline U U01-Z99 & $\begin{array}{l}\text { All other categories } \\
\text { Sve ostale kategorije }\end{array}$ \\
\hline
\end{tabular}

Information about provided services for hospital, outpatient and home treatment, as well as day care, extra services, health care, drug consumption and consumer goods to health care, were analyzed and cross- compared with financial data from the Republic Health Insurance Fund after examination procedure of SHA (version 11).

The cost of individual health care in the Republic of Serbia, according to the main categories of the ICD was grouped into the following scheme and methodology of SHA 11:

- H.C.1. - Hospitalization services are financially expressed by the number of hospital days by groups of diseases (data source: NHIF [26]) multiplied by the cost of hospital day from the current price list of health services NHIF.

- H.C.1.2. - Day care services are registered by groups of diseases and multiplied by the price of the day from the current price list of health services NHIF.

- H.C.1.3. - Funds spent for the treatment of ambulatory patients are determined by the number of out- patient treatment services (data source: NHIF) multiplied by the current price list of health services NHIF.

- H.C.1.4 - Home health services cost were expressed by the services provided at home treatment (data source: planning table for health centers that handles NHIF) multiplied by the price of the current price list of health services NHIF.

- H.C.4. - Auxiliary health services (laboratory analysis, diagnostics and medical transportation) are financially expressed by the empirically estimated total number of these service multiplied by the corresponding prices of the current price list of health services NHIF.

- H.C.5.1. - Financial view of drugs and other consumer goods was obtained from the Agency for Medicines and Medical Devices Agency of Serbia.

The sum of items H.C.1, H.C.1.2, H.C.1.3, H.C.1.4, H.C.4. and H.C.5.1. by groups of diseases gave the estimated financial value for the total cost of health care of population in Serbia by groups of diseases ICD.

Retrospective and comparative research methods were applied in the analysis. Data obtained from the National Fund of Statistics (NFS) and the National Bank of Serbia (NBS) were used as well.

The following Tables present groups of diseases codes according to the International Classification of Diseases (Table 1), as well as Table 6 that was used to calculate the cost of individual health care (Table 2).

\section{RESULTS}

The results determined the cost of individual health care by main categories of the ICD The total sum (in RSD, Euros and US Dollars) that was spent for health care of population in Serbia during observed years, according to the ICD is shown in the Table 3.

Total cost for individual health care by major ICD classification in 2010 was $151,331,867,999$ RSD. In regards to the groups of diseases the highest individual cost was allocated for the circulatory system diseases (19.58\%), neoplasms (10.0\%), diseases of the digestive system (9.75\%), nervous system diseases $(8.33 \%)$, infectious and parasitic diseases $(8.99 \%)$, while the least was for congenital anomalies $(0.27 \%)$ (Figure 1). In 2010, the total individual cost for health care by main categories ICD per capita was $€ 195.00$, and in relation to the gross domestic product (GDP) in 2010 it was $5.20 \%$.

$151,614,999,373 \mathrm{RSD}$ in 2011 was the total individual cost for health care by major ICD categories. In relation to the groups of diseases the highest individual cost was allocated for the circulatory system diseases (19.14\%), diseases of the digestive system (9.71\%), infectious and parasitic diseases (8.88\%) and neoplasms $(8.90 \%)$, while the least was for congenital anomalies $(0.30 \%)$ (Figure 2 ). The total cost for individual health care by main categories of ICD in 2011 per capita was $€ 205.00$, and it was $4.77 \%$ of the GDP for that year.

Total cost for individual health care by major ICD categories in 2012 was $166,575,285,407$ RSD. The highest indi- 
Table 2. Table 6 used for cost calculation

Tabela 2. Tabela 6 korišćena za izračunavanje

\begin{tabular}{|c|c|c|c|c|c|c|c|c|c|}
\hline \multirow[t]{2}{*}{\begin{tabular}{|l|} 
Individual health care \\
Individuala zdravstvena zaštita
\end{tabular}} & \multicolumn{4}{|c|}{ HC.1-HC.3 } & \multirow[b]{2}{*}{ 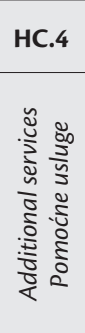 } & \multirow[b]{2}{*}{ 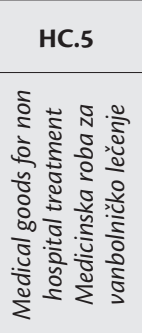 } & \multirow[b]{2}{*}{ 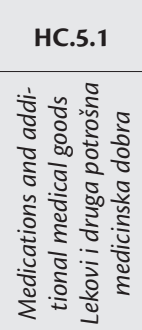 } & \multirow[b]{2}{*}{ 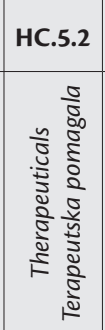 } & \multirow[b]{2}{*}{ 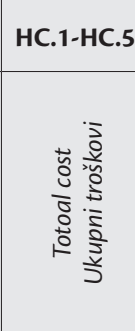 } \\
\hline & 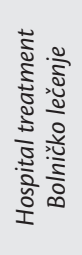 & 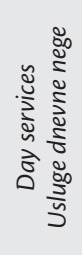 & 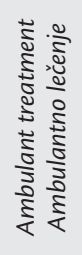 & 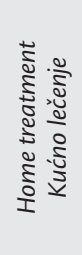 & & & & & \\
\hline \multicolumn{10}{|l|}{$\begin{array}{l}\text { Infectious and parasitic diseases } \\
\text { Infektivne i parazitske bolesti }\end{array}$} \\
\hline \multicolumn{10}{|l|}{$\begin{array}{l}\text { Neoplasms } \\
\text { Tumori }\end{array}$} \\
\hline \multicolumn{10}{|c|}{$\begin{array}{l}\text { Diseases of the blood and blood-forming } \\
\text { organs } \\
\text { Bolesti krvi i krvotvornih organa }\end{array}$} \\
\hline \multicolumn{10}{|l|}{$\begin{array}{l}\text { Endocrine and metabolic diseases } \\
\text { Endokrine bolesti i bolesti metaboliza }\end{array}$} \\
\hline \multicolumn{10}{|l|}{$\begin{array}{l}\text { Mental disorders } \\
\text { Mentalni poremećaji }\end{array}$} \\
\hline \multicolumn{10}{|l|}{$\begin{array}{l}\text { Diseases of the nervous system } \\
\text { Bolesti nervnog sistema }\end{array}$} \\
\hline \multicolumn{10}{|l|}{$\begin{array}{l}\text { Diseases of the circulatory system } \\
\text { Bolesti cirkulatorog sistema }\end{array}$} \\
\hline \multicolumn{10}{|l|}{$\begin{array}{l}\text { Diseases of the respiratory system } \\
\text { Bolesti disajnog sistema }\end{array}$} \\
\hline \multicolumn{10}{|l|}{$\begin{array}{l}\text { Diseases of the digestive system } \\
\text { Bolesti digestivnog sistema }\end{array}$} \\
\hline \multicolumn{10}{|l|}{$\begin{array}{l}\text { Skin and subcutaneous tissue disorders } \\
\text { Bolesti kože i potkožnog tkiva }\end{array}$} \\
\hline \multicolumn{10}{|l|}{$\begin{array}{l}\text { Diseases of the musculoskeletal system } \\
\text { Bolesti mišićno-koštanog sistema }\end{array}$} \\
\hline \multicolumn{10}{|l|}{$\begin{array}{l}\text { Diseases of the genitourinary system } \\
\text { Bolesti urogenitalnog sistema }\end{array}$} \\
\hline \multicolumn{10}{|c|}{$\begin{array}{l}\text { Complications of pregnancy and childbirth } \\
\text { Komplikacije trudnoće i porođaja }\end{array}$} \\
\hline \multicolumn{10}{|l|}{$\begin{array}{l}\text { Perinatal conditions } \\
\text { Perinatalna stanja }\end{array}$} \\
\hline \multicolumn{10}{|l|}{$\begin{array}{l}\text { Congenital malformations } \\
\text { Urođene anomalije }\end{array}$} \\
\hline \multicolumn{10}{|l|}{$\begin{array}{l}\text { Symptoms and pathologies } \\
\text { Simptomi i patološka stanja }\end{array}$} \\
\hline \multicolumn{10}{|l|}{$\begin{array}{l}\text { Injuries, poisoning and consequences } \\
\text { Povrede, trovanja i posledice }\end{array}$} \\
\hline $\begin{array}{l}\text { All other categories } \\
\text { Sve ostale kategorije }\end{array}$ & & & & & & & & & \\
\hline
\end{tabular}

Table 3. Total cost of health care by groups of ICD in Serbia in the period 2010-2015

Tabela 3. Ukupni troškovi za zdravstvenu zaštitu prema grupama MKB u Srbiji u periodu 2010-2015. godine

\begin{tabular}{|l|c|c|c|}
\hline $\begin{array}{l}\text { Year } \\
\text { Godina }\end{array}$ & $\begin{array}{c}\text { Totoal cost } \\
\text { (dinars, RSD) } \\
\text { Ukupni troškovi } \\
\text { (dinari, RSD) }\end{array}$ & $\begin{array}{c}\text { Totoal cost } \\
\text { (euros, } \boldsymbol{\epsilon} \text { ) } \\
\text { Ukupni troškovi } \\
\text { (evri, } \boldsymbol{\epsilon} \text { ) }\end{array}$ & $\begin{array}{c}\text { Totoal cost } \\
\text { (dollars, \$) } \\
\text { Ukupni troškovi } \\
\text { (dolari, \$) }\end{array}$ \\
\hline 2010 & $151,333,139,835$ & $1,434,464,541$ & $1,908,843,843$ \\
\hline 2011 & $151,614,999,374$ & $1,488,057,711$ & $2,076,022,877$ \\
\hline 2012 & $166,972,893,694$ & $1,477,505,475$ & $1,898,282,102$ \\
\hline 2013 & $176,734,078,012$ & $1,563,050,128$ & $2,081,183,208$ \\
\hline 2014 & $183,189,009,509$ & $1,547,596,600$ & $1,875,591,374$ \\
\hline 2015 & $194,128,864,011$ & $1,580,853,941$ & $1,764,807,854$ \\
\hline
\end{tabular}

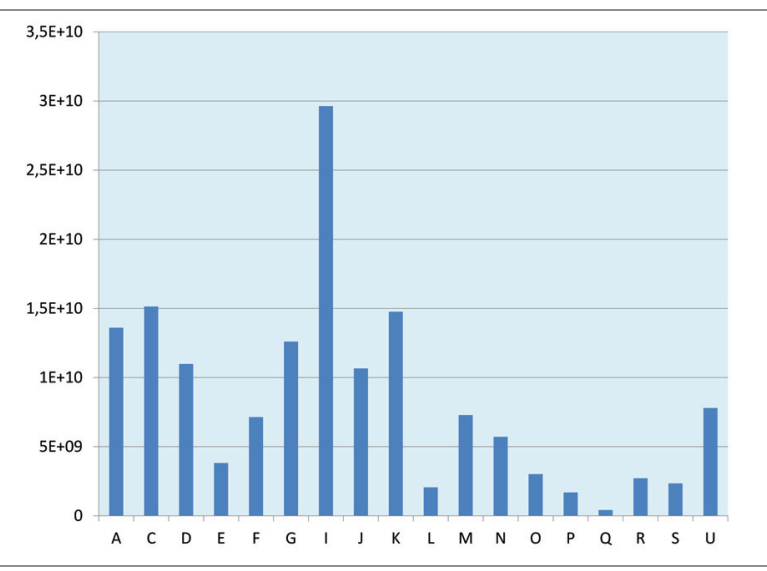

Figure 1. Individual costs for health care, according to the ICD classification in 2010.

Grafikon 1. Individualni troškovi za zdravstvenu zaštitu po MKB klasifikaciji u 2010. godini 


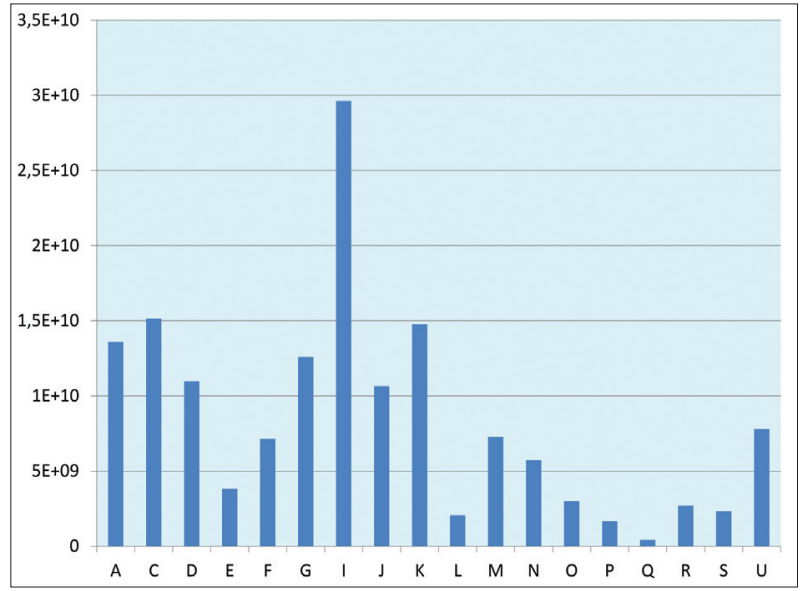

Figure 2. Individual costs for health care, according to the ICD classification in 2011.

Grafikon 2. Individualni troškovi za zdravstvenu zaštitu po MKB klasifikaciji u 2011. godini

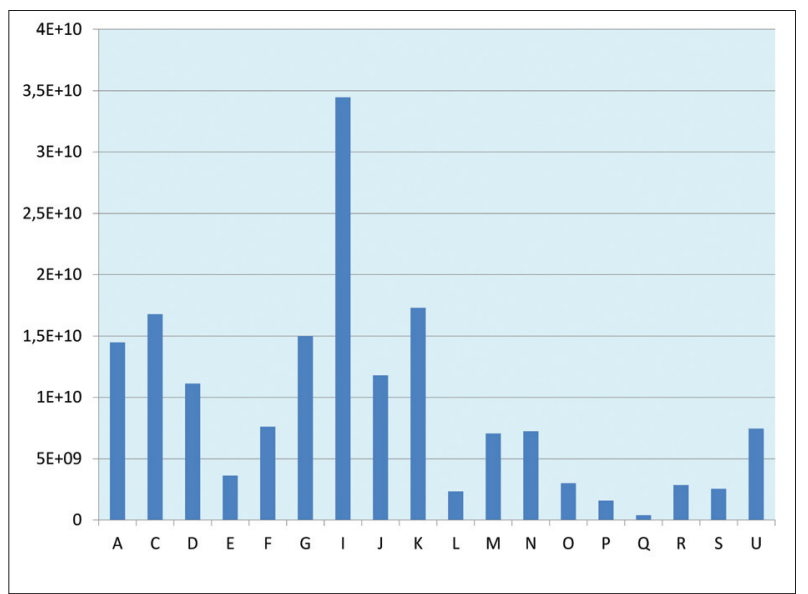

Figure 3. Individual costs for health care, according to the ICD classification in 2012.

Grafikon 3. Individualni troškovi za zdravstvenu zaštitu po MKB klasifikaciji u 2012. godini

vidual cost was observed by the following disease groups: circulatory system diseases (20.69\%), diseases of the digestive system (10.38\%), neoplasms (10.07\%), nervous system $(9.00 \%)$, and infectious parasitic diseases (8.69\%), while the least was for congenital anomalies $(0.23 \%)$ (Figure 3). In 2012, the total individual cost for health care by major ICD categories per capita was $€ 205.00$. That represented $4.97 \%$ of the GDP for the year 2012.

In 2013, the total individual cost for health care by major ICD categories was 176,734,078,012 RSD. By the ICD classification, the greatest individual cost was allocated for the circulatory system diseases (20.44\%), neoplasms (10.84\%), diseases of the digestive system $(10.62 \%)$, nervous system (8.74\%), infectious parasitic diseases (8.51\%), and the least for congenital anomalies $(0.21 \%)$ (Figure 4$)$. Individual cost for health care by main categories of ICD in 2013 per capita was $€ 219.00$, being $4.88 \%$ of the GDP for 2013 .

The total cost for individual health care by major ICD categories in 2014 was 183,189,009,508 RSD. The individual cost was allocated mostly for the circulatory system diseases (18.62\%), nervous system $(11,79)$, diseases of the digestive system (10.74\%), neoplasms (10.62\%), infectious

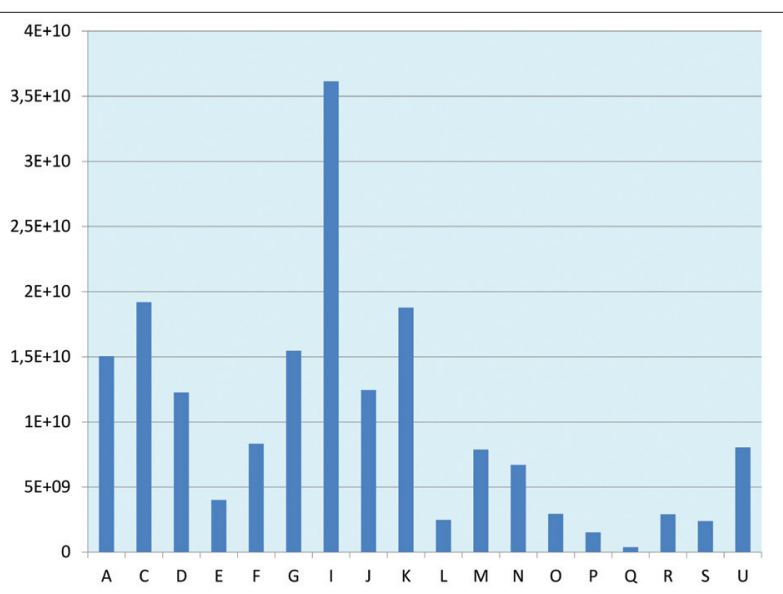

Figure 4. Individual costs for health care, according to the ICD classification in 2013.

Grafikon 4. Individualni troškovi za zdravstvenu zaštitu po MKB klasifikaciji u 2013. godini

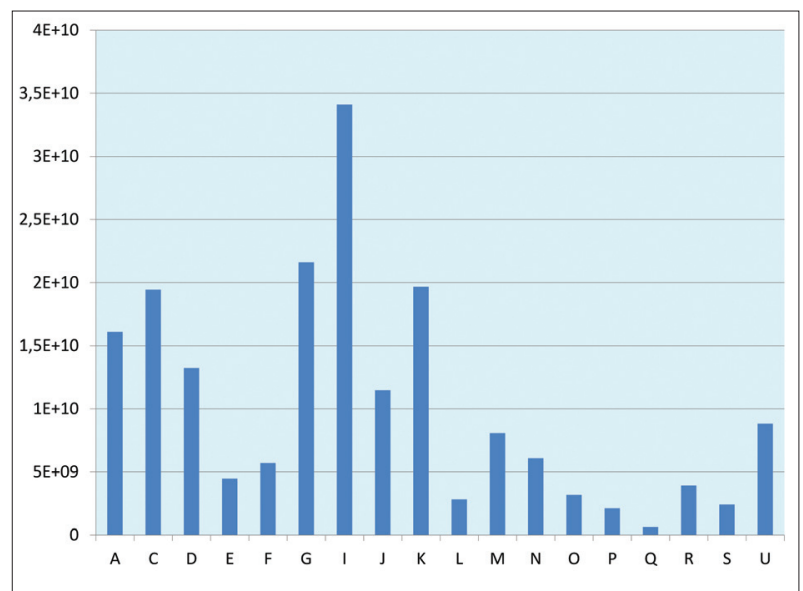

Figure 5. Individual costs for health care, according to the ICD classification in 2014.

Grafikon 5. Individualni troškovi za zdravstvenu zaštitu po MKB klasifikaciji u 2014. godini

and parasitic diseases $(8.79 \%)$, and the least for congenital anomalies $(0.34 \%)$ and perinatal conditions $(1.15 \%)$ (Figure 5). In 2014, the total individual cost for health care by main categories ICD per capita was $€ 217.00$. That was $4.72 \%$ of the GDP for 2014.

The highest cost of individual health care according to the ICD was recorded in 2015 and amounted to $194,128,864,011$ RSD $(€ 1.580 .853 .941 ; \$ 1,764,807,854)$. In 2015, most money was spent on circulatory diseases (19.8\%), diseases of digestive system (10.67\%), neoplasms $(10.13 \%)$, and the least for congenital anomalies (0.32\%). Results are expressed in RSD and shown on the Figure 6 . The total cost for individual health care by major ICD category in 2015 per capita was $€ 223.00$. That was about $4.89 \%$ of the GDP for 2015.

Observed by years (2010-2015) the total cost of individual health care by major ICD categories shows increasing tendency (Figure 7). The highest cost was allocated for cardiovascular diseases. The percentage share of the total individual cost for health care in the period 2010-2015, per capita, expressed in RSD, euros and dollars is shown in the Table 4. 


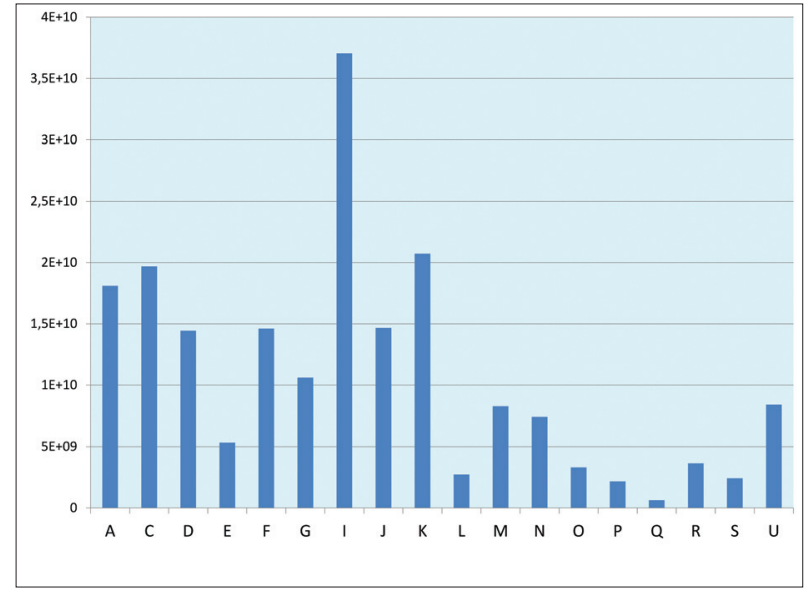

Figure 6. Individual costs for health care, according to the ICD classification in 2015.

Grafikon 6. Individualni troškovi za zdravstvenu zaštitu po MKB klasifikaciji u 2015. godini

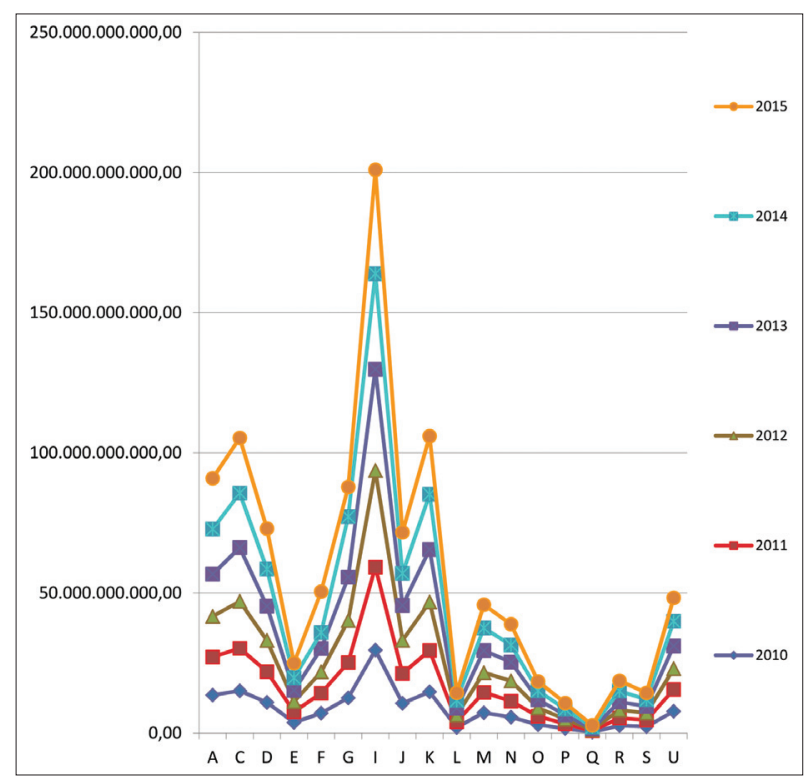

Figure 7. Growth trend of individual costs for health care, according to the ICD categories

Grafikon 7. Trend rasta individualnih troškova za zdravstvenu zaštitu po MKB kategorijama

Individual costs for health care by main categories ICD per capita are also trending upwards from $€ 195$ in 2010 to $223 €$ in 2015 . The percentage share of the total health care costs by major ICD categories in relation to the GDP in the period 2010-2015 had a decline from 5.20\% in 2011 to $4.89 \%$ in 2015 . In 2011 sharp decline was recorded with constant fluctuations in the period 2012-2015 (Table 5).

\section{DISCUSSION}

It has been shown that studies about the cost of health care of patients [2-4] usually focus on the particular disease [5-16], or individual injuries [17], disorders [18] or conditions only [19-24]. Current costs of health care for major groups of diseases ICD are presented in Table 6 of SHA, as part of the National Health account (NHA) [25]. Many users believe that the analysis of table 6 SHA,
Table 4. Individual cost for health care by main categories ICD per capita in the period 2010-2015.

Tabela 4. Individualni troškovi za zdravstvenu zaštitu po glavnim MKB kategorijama po stanovniku u periodu 2010-2015. godine

\begin{tabular}{|l|c|c|c|c|c|c|}
\hline & $\mathbf{2 0 1 0}$ & $\mathbf{2 0 1 1}$ & $\mathbf{2 0 1 2}$ & $\mathbf{2 0 1 3}$ & $\mathbf{2 0 1 4}$ & $\mathbf{2 0 1 5}$ \\
\hline $\begin{array}{l}\text { Cost per capita (RSD) } \\
\text { Troškovi po } \\
\text { stanovniku u dinarima }\end{array}$ & 20,178 & 20,887 & 23,251 & 24,669 & 25,686 & 27,360 \\
\hline $\begin{array}{l}\text { Cost per capita (€) } \\
\text { Troškovi po } \\
\text { stanovniku u evrima }\end{array}$ & 195 & 205 & 205 & 219 & 217 & 223 \\
\hline $\begin{array}{l}\text { Cost per capita (\$) } \\
\text { Troškovi po } \\
\text { stanovniku u } \\
\text { dolarima }\end{array}$ & 259 & 286 & 264 & 291 & 263 & 249 \\
\hline
\end{tabular}

Table 5. Percentage of cost for health care by the GDP from 2010 to 2015

Tabela 5. Procenat troškova za zdravstvenu zaštitu u BDP-u od 2010. do 2015. godine

\begin{tabular}{|l|c|c|}
\hline $\begin{array}{l}\text { Year } \\
\text { Godina }\end{array}$ & $\begin{array}{c}\text { GDP (in millions RSD) } \\
\text { BDP (u milionima RSD) }\end{array}$ & $\begin{array}{c}\text { Percentage of cost from GDP } \\
\text { Udeo troškova u BDP }\end{array}$ \\
\hline 2010 & $2,999,632.9$ & 5.20 \\
\hline 2011 & $3,268,315.6$ & 4.72 \\
\hline 2012 & $3,460,113.4$ & 4.97 \\
\hline 2013 & $3,715,738.8$ & 4.88 \\
\hline 2014 & $3,749,898.8$ & 4.72 \\
\hline 2015 & $3,842,439.3$ & 4.89 \\
\hline
\end{tabular}

entitled "Costs of health care by the main groups of the International Classification of Diseases" is the most important and useful for health politics decision-making. Although there is still no widely accepted clear methodological instructions for establishing table 6 (except the framework, that was used in the present study), international comparisons based on this table have started to perform now [27]. International comparability is actually major advantage of the Table 6. Its disadvantage, however, is that the cost estimates in different countries vary in scope and methodology of the assessment, so that they are based on a large set of assumptions or very small samples.

The total cost of health care for the residents of the Republic of Serbia by the ICD from 2010 to 2015 increased from about 151 billion to almost 194 billion RSD. Expenditure per capita expressed in euros has also increased during the period, from 195 euros in 2010 up to 223 euros in 2015. Expenditure per capita expressed in US dollars during this period recorded the same changes. By groups of diseases, the highest health care cost in the period 2010-2015 in the Republic of Serbia was used for the treatment of patients with cardiovascular diseases, and during this period increased thirty percent. Compared to the increase of funds for other disease groups, this was growth higher than average.

When this cost is compared with findings from Australia, Canada, France, Germany and the Netherlands [27], it is evident that in these countries the largest assets within the healthcare were allocated for cardiovascular diseases, which is most likely the result of today's rapid and stressful lifestyle.

Unlike Serbia, where funds allocated for neoplasm are on the second place, followed by diseases of the digestive 
system, infectious and parasitic diseases, and diseases of the nervous system in other analyzed countries diseases of the nervous system are the second largest participation funding, followed by diseases of digestive system, musculoskeletal system and neoplasm.

At the end of this period (2015) after cardiovascular diseases (19.8\%) that had the highest consumer funds, the second place was for diseases of the digestive system (10.67\%), followed by neoplasm (10.13\%). Cardiovascular diseases (CVD) represents a major economic burden to the health care system in Serbia in terms of direct costs (e.g., hospitalization, rehabilitation, doctor visits, drugs) and indirect costs related to the mortality and morbidity (e.g., productivity loss due to premature death, and short-term or long-term disability). When the results of the cost of CVD in Serbia is compared with the same cost from Australia, Canada and some European countries, it is evident that in these countries, the situation tends to be very similar in terms of health care costs.

A review of studies published in Australia, revealed that cardiovascular diseases had the highest level of health care expenditure compared to any group of diseases in Australia, and that puts them in front of the funds allocated for oral health, mental disorders, and musculoskeletal diseases. According to their research, spending on CVD has remained relatively stable at around $12 \%$ of all expenditures for the period 2000-2009, while the cost of CVD in Serbia is still increasing [28]. In the observed period the total cost reached 19\% of all health care costs in 2015.

When compared by years, the total health care cost by major ICD categories showed tendency of growth, increasing by almost thirty percent. Rising costs in the Republic of Serbia for the treatment of diseases over the years suggest insufficient investment in prevention, public health services, capital investment and other functions related to the health care.

The percentage share of health care costs by major ICD categories by the GDP for the period 2010-2015 dropped from $5.20 \%$ to $4.89 \%$ in 2015 showing that there is room for more funds to be allocated to the health care. There are no available data for other countries and other years so data are not comparable.

\section{CONCLUSION}

Individual costs of treating patients in the period 20102015 increased by thirty percent and the largest funds in Serbia was allocated to treat people with cardiovascular diseases. The cost of treating cardiovascular diseases is likely to continue to grow due to increased stress, bad habits, increased rates of obesity and aging society. To minimize steadily increasing individual costs for cardiovascular diseases, it is crucial to work on prevention and promotion of CVD and development of a comprehensive study that will provide detailed understanding of the cost of CVD and its main drivers.

\section{REFERENCES}

1. Segel JE. Cost-of-Illness Studies - A Primer. RTI International. RTIUNC Center of Excellence in Health Promotion Economics. 2006. http://www.ppge.ufrgs.br/giacomo/arquivos/cd\%20congresso\%20 gramado/artigos/segel-2006.pdf

2. Rice DP. Cost of illness studies: what is good about them? Inj Prev. 2000; 6:177-9. [DOl: 10.1136/ip.6.3.177]

3. Guvenc K, Wertheimer A. What are the top most costly diseases for USA? The alignment of burden of illness with prevention and screening expenditures. 2010; 10(2):1174-8.

[DOl: $10.4236 /$ health.2010.210172]

4. Bloom BS, Bruno Dj, Maman DY, Jayadevappa R. Usefulness of US cost of illness studies in healthcare decision making. Pharmacoeconomics. 2001; 19:207-13. [DOI: 10.1016/S0090-4295(00)01033-5] [PMID: 11284384]

5. Goetzel RZ, Long SR, Ozminkowski RJ, Hawkins K, Wang S, Lynch W. Health absence, disability, and presenteeism cost estimates of certain physical and mental health conditions affecting U.S. employers. J Occup Environ Med. 2004; 46:398-412. [PMID: 15076658]

6. Honeycutt AA, Segel JE, Hoerger TJ, Finkelstein EA. Comparing Cost-of-Illness Estimates from Alternative Approaches: An Application to Diabetes. Health Serv Res. 2009; 44(1):303-20.

[DOI: 10.1111/j.1475-6773.2008.00909.x] [PMID: 19146569]

7. Centers for Disease Control and Prevention (CDC). Economic costs associated with mental retardation, cerebral palsy, hearing loss, and vision impairment - United States, 2004. Morb Mortal Wkly Rep. 2004; 53:57-9. [PMID: 14749614]

8. Bloom BS, Pouvourville N, Straus WL. Cost of Illness of Alzheimer's Disease: How Useful Are Current Estimates? Gerontologist. 2003; 43(2):158-64. [DOI: 10.1093/geront/43.2.158] [PMID: 12677073]

9. Rapoport SI, Basselin M, Kim HW, Rao JS. Bipolar Disorder And Mechanisms Of Action Of Mood Stabilizers. Brain Res Rev. 2009; 61(2):185-209. [DOI: 10.1016/j.brainresrev.2009.06.003] [PMID: 19555719]

10. Begley CE, Famulari M, Annegers JF, Lairson DR, Reynolds TF, Coan $\mathrm{S}$, et al. The cost of epilepsy in the United States: an estimate from population-based clinical and survey data. Epilepsia. 2000; 41:34251. [DOI: 10.1111/j.1528-1157.2000.tb00166.x] [PMID: 10714408]

11. Javitz HS, Ward MM, Watson JB, Jaana M. Cost of illness of chronic angina. Am J Manag Care. 2004; 10(11 Suppl):S358-69. [PMID: 15603245]

12. Lazar MA. How obesity causes diabetes: not a tall tale. Science. 2005; 307:373-5. [DOI: 10.1126/science.1104342] [PMID: 15662001]

13. Lowell BB, Shulman Gl. Mitochondrial dysfunction and type 2 diabetes. Science. 2005; 307:384-7. [DOI: 10.1126/science.1104343] [PMID: 15662004]

14. Hogan P, Dall T, Nikolov P; American Diabetes Association. Economic costs of diabetes in the US in 2002. Diabetes Care. 2003; 26:917-32. [DOI: 10.2337/diacare.26.3.917] [PMID:12610059]

15. Szucs TD, Berger K, Fisman DN, Harbarth S. The estimated economic burden of genital herpes in the United States. An analysis using two costing approaches. BMC Infect Dis. 2001; 1:5. [DOI: 10.1186/1471-2334-1-5] [PMID: 11472635]

16. Liu JL, Maniadakis N, Gray A, Rayner M. The economic burden of coronary heart disease in the UK. Heart. 2002; 88:597-603. [PMID: 12433888]

17. McDermid RC. What's new in critical illness and injury science? The costs of having a fall in Qatar! Int J Crit Illn Inj Sci. 2013; 3(1):1-2. [DOI: 10.4103/2229-5151.109405]

18. Fix A, Gafen A, Hughen H, Hunter K, Barg F. Using freelisting to understand shared decision making in ADHD: Parents' and pediatricians' perspectives. Patient Educ Couns. 2011; 84(2):236-44. [DOI: 10.1016/j.pec.2010.07.035] [PMID: 20797833]

19. Yelin E, Trupin L, Cisternas M, Eisner M, Katz P, Blanc P. A national study of medical care expenditures for respiratory conditions. Eur Respir J. 2002; 19:414-21. [DOI: 10.1183/09031936.02.00522001] [PMID: 11936516]

20. Yelin E, Herrndorf A, Trupin L, Sonneborn D. A national study of medical care expenditures for musculoskeletal conditions: the 
impact of health insurance and managed care. Arthritis Rheum. 2001; 44:1160-9.

[DOl: 10.1002/1529-0131(200105)44:5<1160:AID-ANR199>3.0.CO;2-Y] [PMID: 11352250]

21. Roux L, Donaldson C. Economics and obesity: costing the problem or evaluating solutions? Obes Res. 2004; 12:173-9.

[DOI: 10.1038/oby.2004.23]

22. Molinier L, Bauvin E, Combescure C, Castelli C, Rebillard X, Soulié $M$, et al. Methodological Considerations in Cost of Prostate Cancer Studies: A Systematic Review Value in Health. 2008; 11(5):878-85. [DOl: 10.1111/j.1524-4733.2008.00327.x]

23. Flegal KM, Graubard BI, Williamson DF, Gail MH. Excess deaths associated with underweight, overweight, and obesity. JAMA. 2005: 293:1861-7. [DOl: 10.1001/jama.293.15.1861] [PMID: 15840860]

24. Finkelstein EA, Fiebelkorn IC, Wang G. National medical spending attributable to overweight and obesity: how much and who's paying? Health Aff (Millwood). 2004; Suppl Web Exclusives:W3-219-26. [DOI: 10.1377/hlthaff.w3.219] [PMID: 14527256]
25. OECD (2000), A System of Health Accounts (Version 11.0), Paris

26. Institute of Public Health of Serbia "Dr Milan Jovanović Batut". Zdravstveno-statistički godišnjak Republike Srbije. Beograd: Elit medika; 2005-2015.

27. Heijink R, Renaud T. Cost-of-illness studies: a five-country methodological comparison (Australia, Canada, France, Germany and the Netherlands). HealthPolicy. 2008; 88(1):49-61.

[DOI: 10.1016/j.healthpol.2008.02.012]

28. Gajic-Stevanovic M, Dimitrijević S, Živković S, Teodorović N, Perišić-Rajnicke D. Troškovi zdravstvene zaštite u Srbiji prema međunarodnoj klasifikaciji bolesti za period 2004-2009. godine. Stomatološki glasnik Srbije. 2011; 58(3):127-38.

[DOI: 10.2298/SGS1103127G] 


\title{
Troškovi individualne zdravstvene zaštite u Srbiji po međunarodnoj klasifikaciji bolesti za period 2010-2015. godine
}

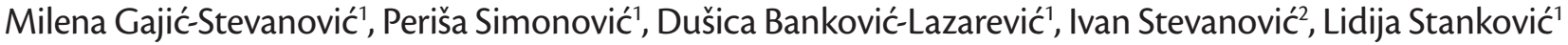 \\ ${ }^{1}$ Institut za javno zdravlje Srbije „Milan Jovanović-Batut", Beograd, Srbija; \\ ${ }^{2} \mathrm{ABC}$ Tutor
}

\begin{abstract}
KRATAK SADRŽAJ
Uvod U svetu raste interesovanje za izračunavanjem troškova lečenja određenih bolesti. Ova vrednost predstavlja breme kojim određena bolest ili grupa oboljenja opterećuje društvo u uslovima globalne krize (Segel 2006). Godine 2000. Organizacija za ekonomski razvoj država (OECD) formirala je Sistem zdravstvenih računa (SZR), okvirno metodološko uputstvo za izračunavanje troškova lečenja bolesti.

Cilj ovog rada bio je da se utvrde troškovi individualne zdravstvene zaštite u Srbiji prema Međunarodnoj klasifikaciji bolesti (MKB) u periodu 2010-2015. godine.

Materijal i metode rada Urađena je retrospektivna i komparativna analiza zdravstvenih statističkih podataka iz baze Instituta za javno zdravlje Srbije i finansijskih podataka Republičkog fonda za zdravstveno osiguranje za period 2010-2015. godine. Finansijski podaci sa podacima o uslugama bolničkog, ambulantnog i kućnog lečenja, pomoćnim uslugama zdravstvene zaštite, potrošnji lekova i potrošnih dobara u zdravstvu su analizirani primenom SZR metodologije.

Rezultati Tokom posmatranog perioda najveći trošak za lečenje bolesnika ostvaren je 2015. godine, a iznosio je 194.128.864.011 dinara (1.580.853.941 evra; 1.764.807.854 dolara), dok je najmanji ostvaren 2010. godine, a bio je 151.333.139.835 dinara (1.434.464.541 evra; 1.908 .843 .843 dolara).

Zaključak Komparativna analiza troškova lečenja bolesti je pokazala da su troškovi lečenja bolesnika u periodu 2010-2015. porasli trideset posto, a da su najveća novčana sredstva u Srbiji izdvojena za lečenje osoba sa bolestima cirkulatornog sistema.

Ključne reči: troškovi bolesti; zdravstvena potrošnja; zdravstveni računi; kardiovaskularne bolesti
\end{abstract}

\section{UVOD}

Zdravstvena zaštita je jedna od najvažnijih ljudskih delatnosti i jedna od najdinamičnijih u pogledu rasta troškova za njeno obezbeđenje. Brojna dostignuća u medicini, farmaceutici, medicinskim tehnologijama, utiču na poboljšanje zdravstvenog stanja ljudi u većini zemalja, ali i na rast troškova, pa je briga za uspostavljanje efikasnosti i efektivnosti zdravstvene zaštite sve više u fokusu zdravstvene politike. Troškovi zdravstvene zaštite predstavljaju teret kojim određena bolest ili grupa oboljenja opterećuje društvenu zajednicu [1].

Potreba za realnim prikazom finansijskih podataka u zdravstvenoj zaštiti, a posebno onih koji se odnose na praćenje troškova za lečenje bolesnika od određenih bolesti nameće se kao neophodnost. U skladu sa tim poslednjih godina raste interesovanje za izračunavanje troškova lečenja bolesnika $[2,3,4]$, a studije širom sveta obrađuju kako pojedine bolesti [5-16], tako i povrede [17], poremećaje [18] i stanja [19-24].

Godine 2000. Organizacija za ekonomski razvoj država (Organisation for Economic Co-operation and Development $O E C D$ ) formirala je Sistem zdravstvenih računa (SZR), koji je formulisao okvirno metodološko uputstvo za izračunavanje cene lečenja bolesnika, kroz tabelu broj 6. Do pojave novog metodološkog uputstva SZR 2011. koristila se tabela broj $6 \mathrm{u}$ SZR [25], kao deo Nacionalnog zdravstvenog računa (NZR). U pomenutoj tabeli prikazani su tekući troškovi zdravstvene zaštite prema glavnim grupama oboljenja Međunarodne klasifikacije bolesti (MKB).

U Sistemu zdravstvenih računa su kao troškovi INDIVIDUALNE zdravstvene zaštite definisani svi oni troškovi u zdravstvenom sistemu koji ne uključuju kolektivnu zdravtsvenu zaštitu, koju čine usluge javnog zdravstva, kolektivna prevencija, zdravstveno osiguranje, zdravstvena administracija i troškovi za vršenje funkcija u vezi sa zdravstvenom zaštitom.
Cilj ovog rada je bio da se izvrši komparativna analiza troškova individualne zdravstvene zaštite u Republici Srbiji prema glavnim grupama oboljenja MKB za period 2010-2015. godine.

\section{MATERIJAL I METODE RADA}

Urađena je komparativna retrospektivna analiza statističkih podataka iz baze Instituta za javno zdravlje Srbije (IZJZS) i finansijskih podataka Republičkog fonda za zdravstveno osiguranje (RFZO) za period 2010-2015. godine.

Podaci o izvršenim uslugama bolničkog, ambulantnog i kućnog lečenja, kao i dnevne nege, pomoćnim uslugama zdravstvene zaštite, potrošnji lekova i potrošnih dobara u zdravstvu analizirani su i ukršteni su sa finansijskim podacima iz Republičkog fonda za zdravstveno osiguranje po metodološkom uputstvu SZR (verzija 11).

Troškovi individualne zdravstvene zaštite u Republici Srbiji prema glavnim kategorijama MKB rađeni su po sledećoj shemi i metodologiji SZR 11:

- H.C.1. - usluge bolničkog lečenja su finansijski izražene tako što je broj bolničkih dana po grupama bolesti (izvor podataka: IZJZS [26]) pomnožen sa cenom bolničkog dana iz važećeg Cenovnika zdravstvenih usluga RFZO;

- H.C.1.2. - usluge dnevne nege su registrovane po grupama bolesti i pomnožene sa cenom dana iz važećeg Cenovnika zdravstvenih usluga RFZO;

- H.C.1.3 - finansijska sredstva utrošena za ambulantno lečenje bolesnika dobijena su tako što je broj usluga ambulantnog lečenja (izvor podataka: IZJZS) pomnožen sa cenom iz važećeg Cenovnika zdravstvenih usluga RFZO;

- H.C.1.4. - usluge kućnog lečenja finansijski su izražene tako što su usluge kućnog lečenja (izvor podataka: planske tabele za domove zdravlja koje obrađuje IZJZS) pomno- 
žene sa cenom iz važećeg Cenovnika zdravstvenih usluga RFZO;

- H.C.4. - pomoćne usluge zdravstvene zaštite (laboratorijske analize, dijagnostika i prevoz bolesnika) finansijski su izražene tako što je iskustveno procenjen ukupan broj tih usluga pomnožen s odgovarajućim cenama iz važećeg Cenovnika zdravstvenih usluga RFZO;

- H.C.5.1. - finansijski prikaz utroška lekova i drugih potrošnih dobara dobijen je od Agencije za lekove i medicinska sredstva Srbije.

Zbir stavki H.C.1, H.C.1.2, H.C.1.3, H.C.1.4, H.C.4. i H.C.5.1. po grupama bolesti daje procenjenu finansijsku vrednost ukupne cene zdravstvene zaštite stanovnika Srbije prema grupama oboljenja MKB.

$\mathrm{U}$ analizi su primenjene komparativna i retrospektivna metoda istraživanja. Za analizu su korišćeni i podaci Republičkog fonda za statistiku (RZS) i Narodne banke Srbije (NBS).

U narednim tabelama prikazane su šifre grupa oboljenja prema Međunarodnoj klasifikaciji bolesti (Tabela 1), kao i Tabela 6, koja se koristi za izračunavanje troškova individualne zdravstvene zaštite (Tabela 2).

\section{REZULTATI}

Rezultati su odredili troškove individualne zdravstvene zaštite po glavnim kategorijama Međunarodne klasifikacije bolesti (MKB) (Tabela 3).

Ukupna novčana sredstva (izražena u dinarima, evrima i američkim dolarima) koja su utrošena na zdravstvenu zaštitu stanovnika Srbije tokom posmatranih godina, prema glavnim grupama oboljenja MKB, prikazana su u tabeli 3.

Ukupni individualni troškovi za zdravstvenu zaštitu po glavnim MKB kategorijama u 2010. godini bili su 151.331.867.999 dinara. Posmatrano po grupama bolesti najveći individualni troškovi su izdvojeni za bolesti cirkulatornog sistema (19,58\%), neoplazme (10\%), bolesti digestivnog sistema (9,75\%), bolesti nervnog sistema $(8,33 \%)$, infektivne i parazitarne bolesti $(8,99 \%)$, dok najmanje za urođene anomalije $(0,27 \%)$ (Grafikon 6). U 2010. godini ukupni individualni troškovi za zdravstvenu zaštitu po glavnim MKB kategorijama po glavi stanovnika iznosili su 195,00 evra, dok je procenat ukupnih individualnih troškova u odnosu na GDP za 2010. godinu iznosio 5,20\%.

151.614.999.373 dinara u 2011. godini bili su ukupni individualni troškovi za zdravstvenu zaštitu po glavnim MKB kategorijama. Posmatrano po grupama bolesti najveći individualni troškovi su izdvojeni za bolesti cirkulatornog sistema $(19,14 \%)$, bolesti digestivnog sistema $(9,71 \%)$, infektivne i parazitarne bolesti (8,88\%) i za neoplazme (8,90\%), dok najmanje za urođene anomalije $(0,30 \%)$ (Grafikon 7$)$. Ukupni individualni troškovi za zdravstvenu zaštitu po glavnim MKB kategorijama ukupno u 2011. godini po glavi stanovnika iznosili su 205,00 evra, dok je procenat ukupnih individualnih troškova u odnosu na GDP za 2011. godinu iznosio 4,77\%.

Ukupni individualni troškovi za zdravstvenu zaštitu po glavnim MKB kategorijama u 2012. godini bili su 166.575.285.407 dinara. Najveći individualni troškovi posmatrano po grupama bolesti su izdvojeni za bolesti cirkulatornog sistema (20,69\%), bolesti digestivnog sistema (10,38\%), neoplazme (10,07\%), bolesti nervnog sistema $(9,00 \%)$, infektivne i parazitarne bolesti $(8,69 \%)$, dok najmanje za urođene anomalije $(0,23 \%)$ (Grafikon 8). U 2012. godini ukupni individualni troškovi za zdravstvenu zaštitu po glavnim MKB kategorijama ukupno po glavi stanovnika iznosili su 205,00 evra, dok je procenat ukupnih individualnih troškova u odnosu na GDP za 2012. godinu iznosio 4,97\%.

U 2013. godini ukupni individualni troškovi za zdravstvenu zaštitu po glavnim MKB kategorijama bili su 176.734.078.012 dinara. Posmatrano po grupama bolesti, najveći individualni troškovi su izdvojeni za bolesti cirkulatornog sistema (20,44\%), neoplazme $(10,84 \%)$, bolesti digestivnog sistema (10,62\%), bolesti nervnog sistema $(8,74 \%)$, infektivne i parazitarne bolesti $(8,51 \%)$, a najmanje za urođene anomalije $(0,21 \%)$ (Grafikon 9$)$. Individualni troškovi za zdravstvenu zaštitu po glavnim MKB kategorijama ukupno u 2013. godini po glavi stanovnika iznosili su 219,00 evra, dok je procenat ukupnih individualnih troškova u odnosu na GDP za 2013. godinu iznosio 4,88\%.

Ukupni individualni troškovi za zdravstvenu zaštitu po glavnim MKB kategorijama u 2014. godini bili su 183.189.009.508 dinara. Najveći individualni troškovi posmatrano po grupama bolesti su izdvojeni za bolesti cirkulatornog sistema (18,62\%), bolesti nervnog sistema $(11,79)$, bolesti digestivnog sistema $(10,74 \%)$, neoplazme $(10,62 \%)$, infektivne i parazitarne bolesti $(8,79 \%)$, a najmanje za urođene anomalije $(0,34 \%)$ i perinatalna stanja (1,15\%) (Grafikon 10). U 2014. godini ukupni individualni troškovi za zdravstvenu zaštitu po glavnim MKB kategorijama po glavi stanovnika iznosili su 217,00 evra, dok je procenat ukupnih individualnih troškova u odnosu na GDP za 2014. godinu iznosio 4,72\%.

Najveći trošak za individualnu zdravstvenu zaštitu po Međunarodnoj klasifikaciji bolesti MKB-10 je ostvaren 2015. godine i iznosio je 194.128.864.011 dinara (1.580.853.941 evra; 1.764.807.854 dolara). U 2015. godini najviše je potrošeno na bolesti krvotoka (19,08\%), bolesti digestivnog sistema (10,67\%), neoplazme $(10,13 \%)$, a najmanje za urođene anomalije $(0,32 \%)$. Rezultati izraženi u dinarima prikazani su u grafikonu broj 11. Ukupni individualni troškovi za zdravstvenu zaštitu po glavnim MKB kategorijama u 2015. godini po glavi stanovnika iznosili su 223,00 evra, dok je procenat ukupnih individualnih troškova u odnosu na GDP za 2015. godinu iznosio 4,89\%. Posmatrano po godinama (2010-2015), ukupni individualni troškovi za zdravstvenu zaštitu po glavnim MKB kategorijama (grupe bolesti po MKB-10 klasifikaciji) imaju tendenciju rasta, izraženu po tekućim cenama (Grafikon 12).

Posmatrano po grupama bolesti, najveći individualni troškovi u periodu od 2010. do 2015. godine su izdvojeni za kardiovaskularne bolesti. Procentualno učešće ukupnih individualnih troškova za zdravstvenu zaštitu u periodu od 2010. do 2015. godine izraženo po glavi stanovnika u dinarima, evrima i dolarima prikazano je u sledećoj tabeli (Tabela 4.).

Individualni troškovi za zdravstvenu zaštitu po glavnim MKB kategorijama po stanovniku imaju trend rasta od 195 evra u 2010. godini do 223 evra u 2015. godini. Procentualno učešće ukupnih troškova za zdravstvenu zaštitu po glavnim ICD-10 kategorijama u bruto domaćem proizvodu (BDP) u periodu od 2010. do 2015. imalo je pad od 5,20\% do 4,89\% 2015. godine. U 2011. godini je zabeležen nagli pad, sa stalnim fluktuacijama u periodu od 2012. do 2015. godine (Tabela 5.). 


\section{DISKUSIJA}

Pregledom istraživanja koja se bave troškovima lečenja bolesnika $[2,3,4]$ uvidelo se da većina studija obrađuje samo pojedine bolesti [5-16], odnosno pojedinačne povrede [17], poremećaje [18] ili stanja [19-24]. Tekući troškovi zdravstvene zaštite prema glavnim grupama bolesti MKB predviđeni su da budu prikazani samo u tabeli 6 SZR, kao deo Nacionalnih zdravstvenih računa (NZR) [25]. Mnogi korisnici analiza NZR smatraju da je upravo tabela $6 \mathrm{u}$ SZR, pod nazivom „Troškovi za zdravstvenu zaštitu po glavnim grupama Međunarodne klasifikacije bolesti“ (kategorije MKB), najvažnija i najkorisnija donosiocima zdravstvene politike. Premda još ne postoji jasno opšteprihvaćeno metodološko uputstvo za izradu tabele 6 (osim okvirnog, koje je korišćeno i u ovom istraživanju), međunarodna poređenja na osnovu ove tabele, iako i dalje vrlo retka, ipak su počela da se vrše [27]. Upravo ta međunarodna uporedivost je glavna prednost tabele 6 . Njen nedostatak, međutim, jeste to što se procene troškova u različitim zemljama razlikuju u obuhvatu i metodologiji procene, tako da se zasnivaju na velikom skupu pretpostavki, odnosno veoma malim uzorcima.

Ukupni troškovi zdravstvene zaštite stanovnika Republike Srbije prema glavnim oboljenjima MKB su se od 2010. do 2015. godine povećali sa oko 151 milijardi na skoro 194 milijarde dinara. Troškovi po glavi stanovnika izraženi u evrima takođe su se tokom posmatranog perioda povećali, i to sa 195 evra u 2010. godini na 223 evra 2015. godine. Troškovi po glavi stanovnika izraženi u dolarima tokom posmatranog perioda beleže iste promene.

Posmatrano po grupama bolesti, najveći troškovi zdravstvene zaštite u periodu od 2010. do 2015. godine u Republici Srbiji izdvojeni su za lečenje osoba sa kardiovaskularnim oboljenjima, a tokom posmatranog vremenskog perioda povećani su za trideset procenata. To, u poređenju s rastom finansijskih sredstava za druge grupe bolesti, predstavlja rast koji je viši od prosečnog.

Kada se rezultati ovih troškova uporede sa nalazima iz Australije, Kanade, Francuske, Nemačke i Holandije [27], vidi se da se i u tim zemljama najveća sredstva u okviru zdravstvene zaštite izdvajaju za kardiovaskularna oboljenja, što je najverovatnije posledica današnjeg ubrzanog i stresnog načina života.

Za razliku od Srbije, gde se sredstva izdvojena za tumore nalaze na drugom mestu po potrošnii u posmatranom periodu, a prate ih bolesti digestivnog sistema, infektivne i parazitarne bolesti i bolesti nervnog sistema, u pomenutim zemljama bolesti nervnog sistema se nalaze na drugom mestu po učešću finansijskih sredstava, a slede ih bolesti digestivnog sistema, koštano-mišićnog sistema i tumori.

Na kraju posmatranog perioda, posle kardiovaskularnih bolesti (19,08\%), koje beleže najveću potrošnju finansijskih sredstava, na drugom mestu sa najvećom potrošnjom finansijskih sredstava su bolesti digestivnog sistema (10,67\%), a slede neoplazme (10,13\%). Kardiovaskularne bolesti (KVB) predstavljaju veliki ekonomski teret za sistem zdravstvene zaštite u Srbiji u smislu direktnih troškova (npr. hospitalizacija, rehabilitacija, poseta lekaru, lekovi) i indirektnih troškova vezanih za mortalitet i morbiditet (na primer, gubici produktivnosti zbog prerane smrti i kratkoročni ili dugoročni invaliditet). Kada su rezultati troškova KVB u Srbiji porede sa pregledom studija i njihovih nalaza iz Australije, Kanade i nekih evropskih zemlja, evidentno je da u ovim zemljama situacija teži da bude veoma slična $u$ smislu zdravstvenih troškova.

Pregled studija objavljenih u Australiji pokazuje da kardiovaskularne bolesti predstavljaju najviši nivo zdravstvene potrošnje u odnosu na bilo koju grupu bolesti u Australiji, što ih stavlja ispred potrošnje za oralno zdravlje, mentalne poremećaje i mišićno-skeletna oboljenja. Prema australijskom istraživanju, potrošnja za KVB je ostala relativno stabilna, na oko $12 \%$ svih rashoda za period 2000-2009. godine zdravstvene zaštite, dok su troškovi za KVB u Srbiji u stalnom porastu [28]. U posmatranom periodu su dostigli 19\% svih troškova zdravstvene zaštite u 2015. godini.

Posmatrano po godinama, ukupni troškovi zdravstvene zaštite po glavnim MKB-10 kategorijama su pokazali tendenciju rasta i povećani su skoro trideset procenata. Ova činjenica govori u prilog rastu troškova u Republici Srbiji za lečenje bolesti tokom godina, i nedovoljnim ulaganjima u prevenciju, usluge javnog zdravlja, kapitalne investicije, kao i druge funkcije koje se odnose na zdravstvenu zaštitu.

Procenat učešća troškova za zdravstvenu zaštitu po glavnim MKB-10 kategorijama u BDP Srbije u periodu 2010-2015. smanjen je sa $5,20 \%$ na $4,89 \%$ u 2015 . godini, i oni pokazuju da postoji prostor za više izdvojenih sredstava za zdravstvenu zaštitu. Ne postoje dostupni podaci za druge zemlje i druge godine, pa tako nisu uporedivi.

\section{ZAKLJUČAK}

Komparativna analiza troškova lečenja bolesti je pokazala da su individualni troškovi lečenja bolesnika u periodu 2010-2015 porasli trideset posto, da su najveća novčana sredstva u Srbiji izdvojena za lečenje osoba sa bolestima kardiovaskularnog sistema. Troškovi za kardiovaskularne bolesti će verovatno nastaviti da rastu, usled povećanog stresa, loših navika, povećane stope gojaznosti i starenja društva. Kako bi se smanjilo stalno povećanje individualnih troškova za kardiovaskularne bolesti, nameće se potreba rada na prevenciji i promociji KVB i izradi sveobuhvatne studije koja će omogućiti detaljno razumevanje troškova KVB i njenih glavnih pokretača. 